\title{
Deconversion Processes in Adolescence-The Role of Parental and Peer Factors
}

\author{
Małgorzata Łysiak*(D), Beata Zarzycka (D) and Małgorzata Puchalska-Wasyl (D) \\ Institute of Psychology, The John Paul II Catholic University of Lublin Al Racławickie 14, 20-950 Lublin, Poland; \\ zarzycka@kul.pl (B.Z.); wasyl@kul.pl (M.P.-W.) \\ * Correspondence: lysiak@kul.pl
}

Received: 4 November 2020; Accepted: 3 December 2020; Published: 11 December 2020

\begin{abstract}
The phenomenon of abandonment of faith, which in psychology is referred to as deconversion, is observed today. Deconversion is particularly widespread in young people. In this paper we examine the parents' religiosity, parents' care, and social support as potential predictors of deconversion in adolescents. Specifically, we aimed to analyse whether or not parents' religiousness, individual differences in childrens' attachment to their parents, and received support from family, friends, and significant others differentiate adolescents in deconversion processes. The hypotheses were tested on a sample of 232 adolescents in a cross-sectional study, which applied three scales. The Adolescent Deconversion Scale, Parental Bonding Instrument, and Multidimensional Scale of Perceived Social Support. The results showed that adolescents having both caring and religious parents are less prone to abandon faith and to moral criticism than those having caring but not religious parents or those having religious but not caring parents. The low social support group was more likely to abandon faith and moral criticism than moderate or high social support groups. Regression analyses revealed that deconversion in adolescence is negatively predicted by the mother's care and friends' support.
\end{abstract}

Keywords: deconversion; adolescence; parental attitudes; social support; religiousness

\section{Introduction}

Adolescence is a period of life described as a time of change, a transition from childhood to adulthood. Young people are confronted with many life opportunities and unexpected changes which require them to formulate a wide range of responses to the challenges of the world. From the developmental perspective and Erikson's theory (Erikson 1963), adolescence is a period characterized by a series of developmental shifts where the identity crisis is the main issue to resolve. Adolescents search for answers to essential questions-for example, Who am I and who will I be? or How can I make the right decisions? - but the answers are only provisional, not true and permanent solutions (Arnett 2000; Łysiak and Oleś 2017). These questions also concern spiritual values, religious beliefs and behaviours, e.g., Does my religion have sense? or Does God really exist? or Should I pray more? or If God really exists why there is so much evil? (Kim and Esquivel 2011). Youths are "hungry" for answers, they strive for finding meaning and purpose, and they look for significant others who would help them with these issues. They also have a great capacity to test their ideas about religious and spiritual issues by checking reality and drawing inferences from this testing. The ability of adolescents to think critically also means that the evidence or arguments they receive about important areas of life from their parents, friends, and authorities are expected to be factual and concrete, just as for their sources of information about God and religion.

This specific time of questioning and undermining reality may cause some youths to turn toward religion, whereas others turn away from religion. In Poland, over the last few years, we have observed 
that youths tend to declare themselves less religious in comparison to their parents (Zarzycka 2009; Zarzycka and Rydz 2014). The percentage of adolescents involved in religion is decreasing, whereas the number of those who do not participate in religious practices or even declare themselves as non-believers is increasing. According to the Polish Public Opinion Poll Centre (CBOS), the group of non-believers is steadily growing, from 5\% in 1996 to $10 \%$ in 2013, 13\% in 2016, and $17 \%$ in 2018. About $44 \%$ of students concluded that the Catholic Church does not meet the people's needs, and especially that it does not provide answers to questions on moral and family problems (Guzik et al. 2015). This can foster a decline in the level of religiousness of young people, especially adolescents, who rebel against church teaching, and finally they may decide to walk away from religion.

Psychologists coined the term deconversion to describe "the depth and intensity of biographical change that can be associated with disbelief and/or disaffiliation" (Paloutzian et al. 2013, p. 408). They refer to Barbour's (Barbour 1994) definition of deconversion, which describes "the loss or deprivation of religious faith" and includes four factors: (1) intellectual doubt in regard to the truth of a system of beliefs, (2) rejection of the way of life of a religious group, (3) emotional suffering (e.g., grief, guilt, loneliness, despair), and (4) disaffiliation from the community. Streib and Keller (2004) identified five dimensions of deconversion: (1) loss of specific religious experiences, such as the loss of meaning and purpose in life; the loss of the experience of God, of trust, or of fear; (2) intellectual doubt, denial, or disagreement with specific beliefs; (3) moral criticism, which includes a rejection of specific prescriptions and/or the application of a new level of moral judgement; (4) emotional suffering, which can consist of a loss of embeddedness, social support, sense of stability, and safety; and (5) disaffiliation from the community, which can consist of a retreat from participation in meetings or from observance of religious practices. From these five dimensions, finally, termination of membership eventually follows. Considering these five characteristics, deconversion cannot be understood as merely disaffiliation from the religious group but rather as an intense process that includes both individual and social aspects-experiential, emotional, intellectual, social, and moral (Paloutzian et al. 2013).

Although extensive literature exists on religiousness in adolescents (e.g., Petts 2009; Desmond et al. 2010; Pearce et al. 2019), most studies have focused on religious development and on the conversion processes (Halama et al. 2013; Kirkpatrick and Shaver 1990; Longo and Kim-Spoon 2014). Less attention has been given to the phenomenon of abandonment of faith during adolescence. The most influential factors that characterize deconversion have been even less investigated (Streib 2020). In this context, the question arises whether factors conducive to the development of religiousness can also be (negative) predictors of deconversion. Leonard et al. (2013) showed that parental religiousness is a significant predictor of their offspring's religiousness; however, many studies in this area have emphasized that important roles in predicting children's religious development are both parents' religiosity and the quality of the parent-child relationship (Ecklund and Park 2007; Flor and Knapp 2001). Early attachment reflecting the parent-child experience is of utmost importance in predicting children's religiousness (Boyatzis et al. 2006; Hardy et al. 2011).

Attachment theory (Ainsworth et al. 1978; Bowlby 1991) is most commonly applied to explain a predictive role of a parent-child relationship for children's religiosity (Granqvist and Hagekull 2003; Greenwald et al. 2018; Kirkpatrick and Shaver 1990). The main assumption of attachment theory is that the mother-child interaction can be a model and a cognitive representation for all later relationships and behaviours, including the relationship with God. Ainsworth et al. (1978) distinguished three attachment styles: (1) secure, describing parents who respond to their children's needs and statements; (2) avoidant, describing parents who are not accessible and responsive; and (3) ambivalent, describing parents who sometimes are caring and responsive and sometimes not. There is considerable empirical support for the idea that attachment-related mental representations can be reflected in religion (Granqvist and Kirkpatrick 2013). Individuals who have been brought up by sensitive caregivers tend to view God or other religious entities as supportive. In contrast, avoidant or ambivalent attachment manifests itself in a view of God as remote and inaccessible (Zarzycka 2018). 
Kirkpatrick and Shaver (1990) formulated two hypotheses that can summarize how a parent-child relationship can influence children's religiosity. The first one, which is referred to as the correspondence hypothesis, posits that people who had secure bonds with their caregivers tend to develop secure relationships with God. The second one, referred to as the compensation hypothesis, states that individuals who experienced insecure attachment with their caregiver would substitute God as a caring parent to compensate for their lack of security and to regulate their emotional distress. For example, insecure attachment has been associated with a sudden increase in behavioural manifestation of religion, such as religious conversion or participation in religious activities (McDonald et al. 2005), which seems to support the compensation hypothesis. Other results have instead been consistent with the correspondence hypothesis: secure attachment was found to be associated with a positive conception of God, whereas insecure attachment was positively associated with religious struggle (Exline et al. 2013; Zarzycka 2018). Granqvist et al. (2007) confirmed that indicators of parental rejection were associated with New Age spirituality and sudden or intense religious changes appearing in life contexts of turmoil. The first systematic study focusing on attachment and deconversion (Greenwald et al. 2018) indicated that the main themes underlying religious conversion and their association with attachment orientations also apply to deconversion. Emotional compensation is the path for people who scored higher on attachment anxiety, whereas exploration is the path for those who scored lower on attachment anxiety and avoidance (Streib 2020).

To sum up, previous research suggests that parental religiousness is a significant predictor of their offspring's religiousness (Leonard et al. 2013). At the same time, studies based on the correspondence hypothesis have showed that secure attachment was associated with a positive God image, whereas insecure attachment was positively associated with seeing God as cruel or distant and that tension was related to religion (Exline et al. 2013; Zarzycka 2018). Thus, when parents are religious and embrace a supportive and nurturing nature, the likelihood of faith transmission to their children increases (Hardy et al. 2011; Hoge et al. 1982; Myers 1996; Okagaki and Bevis 1999). In this context, we pose our first hypothesis:

Hypothesis 1. High religiosity of parents and high parental care are negatively associated with deconversion in adolescents.

Other than the religious and caring family, the other important factor that can significantly influence adolescents' religiosity is social support, not only from family but also from friends and significant others. A number of studies have demonstrated positive relationships between social support and religious involvement (Erickson 1992; Pearce et al. 2019). For example, Donaldson et al. (2019) confirmed that social factors such as relationship quality, spiritual support, and community connection predicted religious/spiritual motivation and identity. The regression models including social constructs revealed that community connections were the best predictors of religious/spiritual salience, even better than the quality of relationships and the supportive faith network of family or friends. Additionally, Park and Slattery (2013) indicated that social support can be considered as a potential mechanism explaining how religiousness may affect mental health. The results of a study by Estarda and her co-workers (2019) confirmed that social support received from inclusion in religious communities and religious practices contributes to positive mental health and well-being. Given the positive link between social support and religiosity (and well-being), our second hypothesis is as follows:

Hypothesis 2. Social support is negatively related to deconversion processes.

In the period of adolescence, youths expand their social ties. Apart from bonds with their family system, they form bonds with friends and peers, who represent crucial agents in the development of social connectedness and interpersonal relationships (Armsden and Greenberg 1987; Gorrese and Ruggieri 2012). Close friends and peers become the primary source of social and emotional support 
(Wilkinson 2004), whereas parents' influence on adolescents' behaviour and development are becoming less important (Harris 1995; Larson and Richards 1991; Steinberg and Morris 2001). Communicating with peers, especially in difficult moments, is very important for solving problems and gaining support (Camara et al. 2017; Dubow et al. 1990; Griffiths et al. 2011; Offer et al. 1991). It is also a significant factor for health and well-being (Heinrich and Gullone 2006; Khasmohammadi et al. 2020; Nica 2019). Some studies have also demonstrated positive relationships between peer support and religious involvement. Brambilla et al. (2015) studied Italian Catholic adolescents involved in a peer group, which demonstrated the internal value of the faith (greater enjoyment, authenticity, and consistency in living according to the faith). The research showed that in this group the level of internalization of the religiosity was higher in comparison with the control group. Another study found that over half of teens with religious beliefs had a close group of friends with the same religious beliefs, whereas non-religious teens had one or zero friends with strong religious beliefs (Smith and Denton 2005). Desrosiers et al. (2011) found that peer spiritual support apart from paternal care and maternal spiritual support was a significant predictor of adolescents' spirituality. Taking these findings into consideration, we hypothesize:

Hypothesis 3. Friends' support is a stronger predictor of deconversion processes than family support.

\section{Materials and Methods}

\subsection{Participants and Procedure}

Participants were 232 adolescents aged between 15 and $18(M=16.80, S D=0.77) ; 58.70 \%$ were female. Participants declared their religious affiliation, religious background, and subjective religiosity. In total, $92.7 \%$ of participants defined themselves as Roman Catholics $(n=215)$. The other religious denominations were as follows: $2.2 \%$ atheists $(n=5)$ and $1.7 \%$ agnostics $(n=5) ; 2.6 \%$ of respondents did not define their religion $(n=6)$. Nearly all participants were brought up as Roman Catholics $(n=230,99.1 \%), 1$ person was raised as Greek Catholic, and 1 defined his or her religion as none. Participants also defined their subjective religious attitude: $5.2 \%(n=12)$ described themselves as very religious, $50 \%(n=116)$ as religious, $23.7 \%(n=55)$ as little religious, $10.8 \%(n=25)$ as having a neutral attitude, $3.9 \%(n=9)$ as non-religious, $3.9 \%(n=9)$ as agnostic, $1.7 \%(n=4)$ as atheist, and $0.8 \%$ did not choose any attitude toward religion $(n=2)$. Most of the respondents $(n=199,86.1 \%)$ declared that they had never changed their religion. Among those who changed their religious affiliation, 27 individuals $(11.7 \%)$ did it once, 3 respondents $(1.3 \%)$ a few times, and 2 respondents $(0.9 \%)$ many times. Participants also reported their parents' religious affiliations and their religious attitudes. Among the mothers whose children described them as having adherence to religion, 38 were described as very religious, 133 as religious, 31 as little religious, and 14 as religiously indifferent. In fathers, 32 were described as very religious, 99 as religious, 53 as little religious, and 22 as religiously indifferent. The study was conducted in 2019 in 10 high schools in the east of Poland. Participation in the study was voluntary and anonymous. Participants from first to third grade participated in the study.

\subsection{Measures}

We applied the Adolescent Deconversion Scale, the Parental Bonding Instrument, and the Multidimensional Scale of Perceived Social Support Scale to our study.

\subsubsection{Adolescent Deconversion Scale}

The 23-item Adolescent Deconversion Scale (ADS) was used to measure the deconversion processes (Nowosielski and Bartczuk 2017). The inventory consists of five subscales: (1) withdrawal from the community (7 items, e.g., The religious community (Church) is becoming less and less important to $\mathrm{me}$ ) - indicates losing the bond with the current group of fellow believers; (2) abandoning faith (6 items, e.g., I have begun to doubt that God exists)—indicates an intensification of doubts and thoughts 
of abandoning faith for agnosticism or atheism; (3) moral criticism (4 items, e.g., I cease to understand why-according to religion - I cannot live the way I want to) -indicates a rejection of the moral principles taught by religion; (4) experiencing transcendental emptiness (6 items, e.g., I have begun to experience emptiness in my religious life) —indicates an intensification of unpleasant emotional states, such as emptiness, a sense of rejection, and sorrow, as well as existential difficulties connected with religion; and (5) deconversion behaviour (5 items, e.g., I rarely attend religious/spiritual services) -indicates a gradual neglect or abandonment of religious activity. The response options were from 0 (completely untrue about me) to 3 (very true about me). The period that the participants considered when assessing the changes in their religiosity was set at the last 12 months. The reliability of ADS calculated by the means of Cronbach's alpha were as follows: withdrawal from the community, 0.87 ; abandoning faith, 0.89; moral criticism, 0.88 ; experiencing transcendental emptiness, 0.85 ; deconversion behaviour, 0.86 ; and the total score for deconversion, 0.95 .

\subsubsection{Parental Bonding Instrument}

The Parental Bonding Instrument (PBI) is a self-report questionnaire widely used for retrospective assessment of the parental contribution to child-parent relationships (Parker et al. 1979). It consists of 25 items -12 addressing parental care and 13 addressing parental control—each rated on a 4-point scale ranging from 0 (very true) to 3 (very untrue). We asked participants to recall the attitudes and behaviours of their mothers and fathers separately. High scores for the instrument's subscale of parental care reflect affection and warmth (e.g., My father or mother enjoys talking things over with me; My father or mother does not talk with me very much), whereas high scores for parental control indicate overprotection and the prevention of independent behaviour (e.g., My father or mother tends to baby me; My father or mother gives me as much freedom as I want). The internal consistency of the PBI obtained in this study was 0.92 for mother's care and 0.88 for father's care; 0.15 for mother's control and 0.27 for father's control. Because of the unsatisfactory score for parental control, we did not use this scale for further analysis.

\subsubsection{Multidimensional Scale of Perceived Social Support}

The Multidimensional Scale of Perceived Social Support (MSPSS) is a 12-item scale designed to measure perceived social support from three sources: family, friends, and significant others (Zimet et al. 1988). The family support subscale records the support an individual receives from family members (e.g., I get the emotional help and support I need from my family; I can talk about my problems with my family). The friends' support subscale records the support which an individual receives from peers (e.g., My friends really try to help me; I have friends with whom I can share my joys and sorrows). Significant others' support is a subscale which records the support from different important people for an individual (e.g., There is a special person who is around when I am in need; I have a special person who is a real source of comfort to me). A total score is calculated by summing the results for all items. Each item is scored on a Likert-type scale from 1 (very strongly disagree) to 7 (very strongly agree), with a higher score indicating higher social support. The MSPSS's reliability indices, assessed with Cronbach's alpha, were as follows: friends, 0.96; family, 0.85; and significant others, 0.91 .

\subsection{Study Design and Statistical Analysis}

This was a cross-sectional study. Statistical analyses were conducted in the following order. First, a correlational analysis was performed to calculate the relationships among ADS, PBI, and MSPSS subscales. Second, using cluster analysis ( $k$-means method), we decided to split the participants into groups differing in (1) their parents' characteristics (religiosity and care) and (2) social support (from friends, family, and significant others). This procedure was based on standard scores (Z-scores). Third, to examine the role of parental care and social support factors in predicting deconversion processes, hierarchical regression analysis was performed. Our aim was to evaluate whether each of the factors would predict unique variance (beyond the roles of the other factors) in adolescents' deconversion. The regression analysis was also based on standard scores (Z-scores). 


\section{Results}

Descriptive statistics and the Pearson correlations for each of the study variables are shown in Table 1. All variables had non-normal distributions. The mean scores on the ADS subscales were positively skewed (from 0.20 , deconversion behaviour to 1.42 , experiencing transcendental emptiness) with more low values. The mean scores on the PBI subscales $(-0.95$, father's care and -1.43 , mother's care), parents' religiosity measures ( -0.70 , father's religiosity and -1.22 , mother's religiosity), and MSPSS subscales (from -1.28 , friends' and family's support to -1.43 , significant others' support) were negatively skewed, with more high values. All the coefficients of skewness were in the range from -2 to 2; thus, the skewness is not strong enough and can be ignored (George and Mallery 2010). Therefore, parametric tests were applied.

Mother's caring attitude correlated negatively with abandoning faith, moral criticism, and experiencing transcendental emptiness. Mother's religiosity correlated negatively with withdrawal from the community, abandoning faith, and moral criticism. Father's religiosity correlated negatively with all measured dimensions of deconversion excluding deconversion behaviour, but father's care did not correlate with deconversion. Friends' and family's support correlated negatively with three deconversion dimensions-abandoning faith, moral criticism, and experiencing transcendental emptiness.

Next, k-means cluster analysis was used twice. First, the respondents were grouped based on their parent's religiousness and the results in the PBI subscale of care. Second, they were grouped based on their results in the MSPSS subscales.

The first cluster analysis identified three groups among the participants. The first one, labelled "caring-religious parents," included 141 people who achieved high scores both on the care subscale of the PBI and on assessments of parental religiousness. The second one, labelled "religious parents," included 33 people who assessed their parents as high on the religiousness dimension and low on the care dimension. The third one, labelled "caring parents," included 47 people who assessed their parents as high on the care dimension but low on religiousness. Figure 1 shows the graphical presentation of the scores obtained in each group.

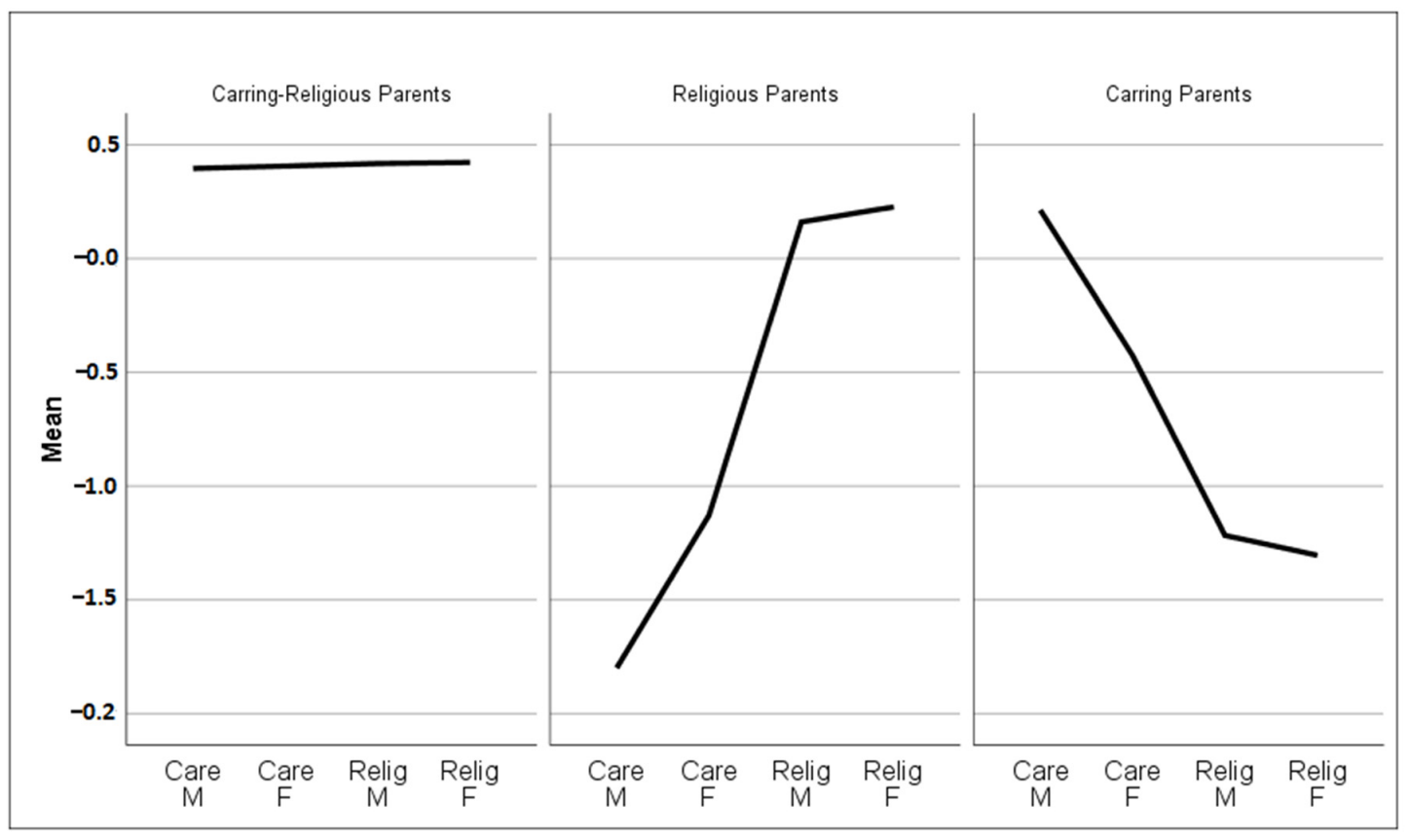

Figure 1. Groups Differentiated by k-means Cluster Analysis of the Data on the Care Subscales of the PBI and Parents' Religiousness. 
Table 1. Intercorrelations between Variables Included in the Study.

\begin{tabular}{|c|c|c|c|c|c|c|c|c|c|c|c|c|c|}
\hline \multicolumn{2}{|c|}{ Variables } & \multirow{2}{*}{$\begin{array}{c}1 \\
-\end{array}$} & \multirow[t]{2}{*}{2} & \multirow[t]{2}{*}{3} & \multirow[t]{2}{*}{4} & \multirow[t]{2}{*}{5} & \multirow[t]{2}{*}{6} & \multirow[t]{2}{*}{7} & \multirow[t]{2}{*}{8} & \multirow[t]{2}{*}{9} & \multirow[t]{2}{*}{10} & \multirow[t]{2}{*}{11} & \multirow[t]{2}{*}{12} \\
\hline 1 & WFC & & & & & & & & & & & & \\
\hline 2 & $\mathrm{AF}$ & $0.64^{* * *}$ & - & & & & & & & & & & \\
\hline 3 & $\mathrm{MC}$ & $0.62^{* * *}$ & $0.77^{* * *}$ & - & & & & & & & & & \\
\hline 4 & ETE & $0.54^{* * *}$ & $0.73^{* * *}$ & $0.65^{* * *}$ & - & & & & & & & & \\
\hline 5 & DB & $0.82^{* * *}$ & $0.47^{* * *}$ & $0.48^{* * *}$ & $0.49^{* * *}$ & - & & & & & & & \\
\hline 6 & Care M & -0.10 & $-0.21^{* * *}$ & $-0.19 * *$ & $-0.19^{* *}$ & -0.06 & - & & & & & & \\
\hline 7 & Care F & -0.04 & -0.08 & -0.08 & -0.12 & 0.01 & $0.50 * * *$ & - & & & & & \\
\hline 8 & Rel M & $-0.16^{*}$ & $-0.19^{* *}$ & -0.17 * & -0.12 & -0.06 & 0.09 & 0.12 & - & & & & \\
\hline 9 & Rel F & $-0.15^{*}$ & $-0.18^{* *}$ & $-0.19^{* *}$ & $-0.15 *$ & -0.05 & 0.02 & $0.26^{* * *}$ & $0.58^{* * *}$ & - & & & \\
\hline 10 & Friends & -0.08 & $-0.19 * *$ & $-0.19 * *$ & $-0.26^{* * *}$ & -0.03 & $0.20 * *$ & $0.21^{* *}$ & -0.03 & 0.02 & - & & \\
\hline 11 & Family & -0.03 & $-0.22 * *$ & -0.14 * & $-0.22 * *$ & 0.04 & $0.60^{* * *}$ & $0.45^{* * *}$ & 0.12 & 0.02 & $0.56^{* * *}$ & - & \\
\hline \multirow[t]{4}{*}{12} & Others & -0.01 & -0.12 & -0.12 & -0.06 & 0.03 & $0.16^{*}$ & 0.08 & -0.01 & 0.06 & $0.69^{* * *}$ & $0.48^{* * *}$ & - \\
\hline & $M$ & 1.35 & 0.67 & 0.89 & 0.67 & 1.35 & 2.32 & 2.09 & 3.71 & 3.40 & 5.58 & 5.50 & 5.75 \\
\hline & $S D$ & 0.98 & 0.85 & 0.87 & 0.78 & 1.00 & 0.67 & 0.77 & 1.02 & 1.16 & 1.39 & 1.26 & 1.40 \\
\hline & Alpha & 0.87 & 0.89 & 0.88 & 0.85 & 0.86 & 0.92 & 0.88 & & & 0.96 & 0.85 & 0.91 \\
\hline
\end{tabular}

Notes: WFC—Withdrawal from the Community, AF-Abandoning Faith; MC—Moral Criticism; ETE-Experiencing Transcendental Emptiness; DB-Deconversion Behaviour; Care M-Mother's Care; Care F-Father's Care; Rel M-Mother's Religiosity; Rel F-Father's Religiosity; Friends—Friends' Support; Family-Family's Support; Others—Significant Others' Support. ${ }^{*} p<0.05 ;{ }^{* *} p<0.01 ;{ }^{* * *} p<0.001$. 
Results of the ANOVA indicated that the three above-mentioned groups differed in scores on the abandoning faith $(\mathrm{F}(2,220)=4.92, p=0.008)$ and moral criticism $(\mathrm{F}(2,220)=4.95, p=0.008)$ subscales. The Scheffe's test was conducted for all comparisons and revealed that participants who assessed their parents as both caring and religious were less prone to abandon faith as well as to criticize moral teaching derived from religion than the other groups. Specifically, adolescents who had both caring and religious parents differed significantly from the group "caring parents," and they almost reached the required level of statistical significance ( $p=0.073$ ) when compared to the group "religious parents" (Table 2).

Table 2. Descriptive Statistics and One-Way Analysis of Variance of Deconversion Processes by Parents' Characteristics Group.

\begin{tabular}{|c|c|c|c|c|c|c|c|c|c|c|c|}
\hline \multirow{3}{*}{ Deconversion } & \multirow{2}{*}{\multicolumn{2}{|c|}{$\begin{array}{c}\text { Group } 1 \\
\begin{array}{c}\text { Caring-Religious } \\
\text { Parents }\end{array}\end{array}$}} & \multirow{2}{*}{\multicolumn{2}{|c|}{$\begin{array}{c}\text { Group } 2 \\
\text { Religious } \\
\text { Parents }\end{array}$}} & \multirow{2}{*}{\multicolumn{2}{|c|}{$\begin{array}{l}\text { Group } 3 \\
\text { Caring } \\
\text { Parents }\end{array}$}} & \multirow{2}{*}{\multicolumn{2}{|c|}{ ANOVA }} & \multirow{2}{*}{\multicolumn{3}{|c|}{ Scheffe Test }} \\
\hline & & & & & & & & & & & \\
\hline & $M$ & $S D$ & $M$ & $S D$ & $M$ & $S D$ & $F(2,220)$ & $p$ & $1: 2$ & $2: 3$ & $1: 3$ \\
\hline WFC & 1.27 & 0.90 & 1.49 & 1.04 & 1.64 & 1.17 & 2.70 & 0.070 & - & - & - \\
\hline $\mathrm{AF}$ & 0.55 & 0.74 & 0.92 & 0.96 & 0.91 & 1.04 & 4.92 & 0.008 & 0.073 & - & 0.037 \\
\hline MC & 0.76 & 0.76 & 1.13 & 0.90 & 1.15 & 1.12 & 4.95 & 0.008 & 0.090 & - & 0.030 \\
\hline ETE & 0.59 & 0.69 & 0.82 & 0.86 & 0.84 & 0.98 & 2.38 & 0.095 & - & - & - \\
\hline DB & 1.30 & 0.95 & 1.49 & 1.07 & 1.49 & 1.11 & 0.94 & 0.392 & - & - & - \\
\hline $\mathrm{D}$ & 0.89 & 0.66 & 1.17 & 0.82 & 1.21 & 0.93 & 4.09 & 0.018 & - & - & 0.047 \\
\hline
\end{tabular}

Notes: WFC—Withdrawal from the Community; AF-Abandoning Faith; MC—Moral Criticism; ETE-Experiencing Transcendental Emptiness; DB-Deconversion Behavior; D—Deconversion.

The second cluster analysis, based on the MSPSS subscales' results, identified three groups differing in social support. The first group, labelled "high social support", included 121 respondents who scored high on the friends', family, and significant others' support subscales of the MSPSS. The second group, labelled "low social support", included 26 respondents who scored low in the friends' and significant others' support subscales and higher but still low in the family support subscale of the MSPSS. The third group, labelled "moderate social support", included 74 respondents who scored generally somewhat below the average: higher in friends and significant others, and lower in the family support subscale of the MSPSS. Figure 2 shows the graphical presentation of the scores obtained in each group.

Results of the one-way analysis of variance (ANOVA) indicated that there were significant differences in abandoning faith $(F(2,220)=5.83, p=0.003)$, moral criticism $(F(2,220)=4.84, p=0.009)$, and experiencing transcendental emptiness $(F(2,220)=6.58, p=0.002)$ between groups differing on social support dimensions. The Scheffe's test revealed that respondents who received low social support obtained significantly higher scores on the abandoning faith and moral criticism subscales, compared to the two other groups. The low social support group scored higher than the high social support group in experiencing transcendental emptiness (Table 3).

Table 3. Descriptive Statistics and One-Way Analysis of Variance of Deconversion Processes by Social Support Group.

\begin{tabular}{|c|c|c|c|c|c|c|c|c|c|c|c|}
\hline \multirow{3}{*}{ Deconversion } & \multirow{2}{*}{\multicolumn{2}{|c|}{$\begin{array}{c}\text { Group 1 } \\
\text { High } \\
\text { Social Support }\end{array}$}} & \multirow{2}{*}{\multicolumn{2}{|c|}{$\begin{array}{c}\text { Group } 2 \\
\text { Low } \\
\text { Social Support }\end{array}$}} & \multirow{2}{*}{\multicolumn{2}{|c|}{$\begin{array}{c}\text { Group } 3 \\
\text { Moderate } \\
\text { Social Support }\end{array}$}} & \multirow{2}{*}{\multicolumn{2}{|c|}{ ANOVA }} & \multirow{2}{*}{\multicolumn{3}{|c|}{ Scheffe Test }} \\
\hline & & & & & & & & & & & \\
\hline & $M$ & $S D$ & $M$ & $S D$ & $M$ & $S D$ & $F(2,220)$ & $p$ & 1:2 & $2: 3$ & $1: 3$ \\
\hline WFC & 1.28 & 0.99 & 1.39 & 1.09 & 1.38 & 0.94 & 0.30 & 0.741 & - & - & - \\
\hline $\mathrm{AF}$ & 0.53 & 0.75 & 1.14 & 0.91 & 0.66 & 0.90 & 5.83 & 0.003 & 0.003 & 0.042 & - \\
\hline MC & 0.77 & 0.81 & 1.33 & 0.98 & 0.83 & 0.84 & 4.84 & 0.009 & 0.009 & 0.036 & - \\
\hline ETE & 0.51 & 0.68 & 1.07 & 0.93 & 0.74 & 0.81 & 6.58 & 0.002 & 0.003 & - & - \\
\hline $\mathrm{DB}$ & 1.32 & 1.01 & 1.27 & 1.07 & 1.35 & 0.96 & 0.06 & 0.941 & - & - & - \\
\hline $\mathrm{D}$ & 0.88 & 0.69 & 1.24 & 0.87 & 0.99 & 0.76 & 2.70 & 0.069 & - & - & - \\
\hline
\end{tabular}

Notes: WFC—Withdrawal from the Community; AF-Abandoning Faith; MC—Moral Criticism; ETE—Experiencing Transcendental Emptiness; DB-Deconversion Behavior; D—Deconversion. 


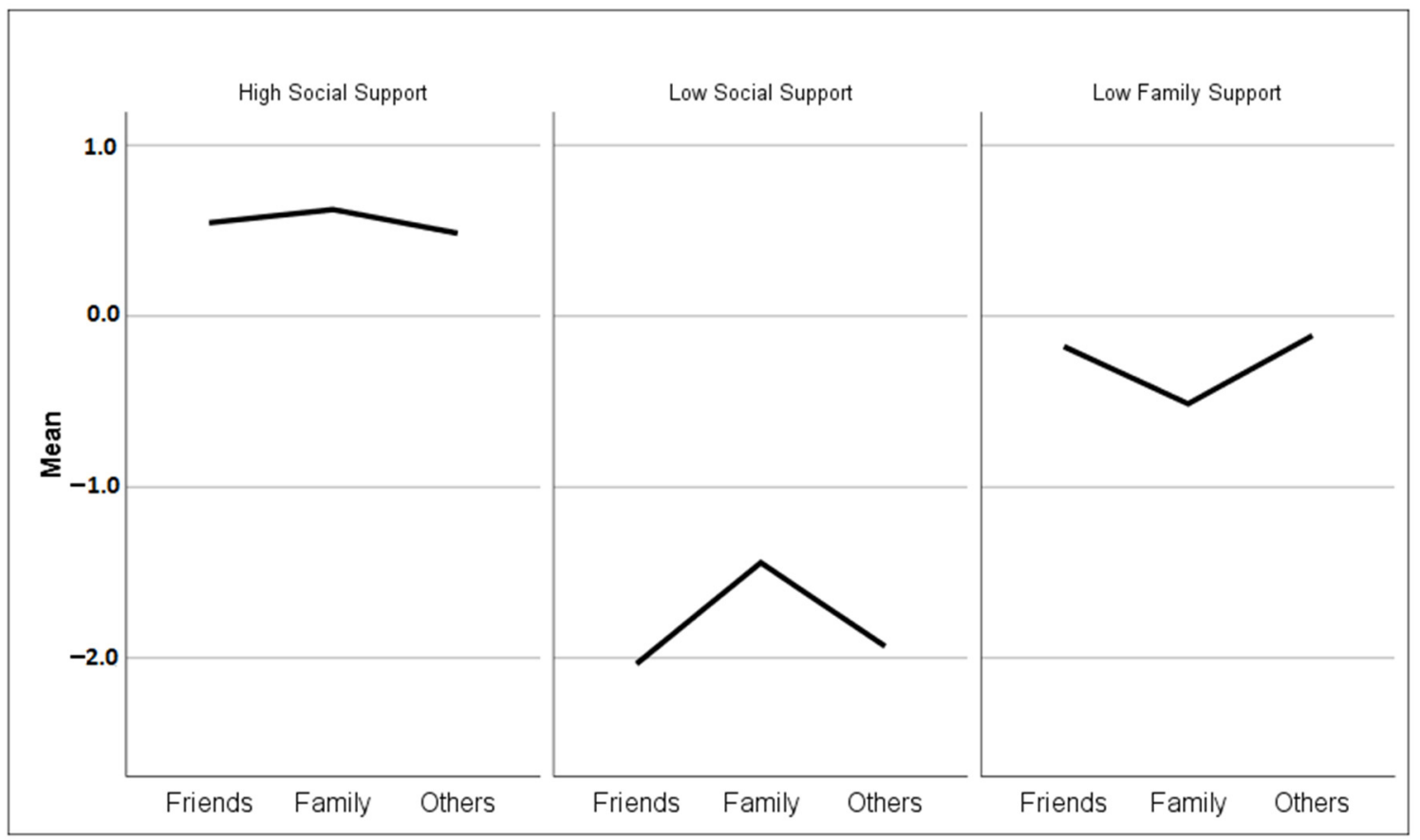

Figure 2. Three Groups Differentiated by k-means Cluster Analysis of the Data on the Friends, Family, and Significant Others Support Subscales of the MSPSS.

Finally, a linear regression analysis was conducted to examine the extent of variance explained in deconversion by all variables measured, after controlling the other predictors. A three-stage hierarchical multiple regression analysis was conducted. At stage 1, mother's and father's care were included to the regression model; at stage 2, mother's and father's religiosity; and at stage 3, support from friends, family, and significant others. The parental factors were included before social support factors since parents' influences come chronologically prior to the social support influences.

Prior to conducing a hierarchical multiple regression, the relevant assumptions of this statistical analysis were tested. An examination of correlations revealed that no independent variables were highly correlated. The only exceptions were friends' and significant others' support $(\mathrm{r}=0.69)$. However, as the collinearity statistics (i.e., tolerance and variance inflation factor (VIF)) were all within accepted limits, the assumption of multicollinearity was deemed to have been met (Hair et al. 2010).

The hierarchical multiple regression with deconversion as a dependent variable revealed that at stage 1 mother's care contributed significantly to the regression model $[F(2,210)=3.61, p=0.029]$, explaining $3 \%$ of the variance in deconversion. Introducing the parents' religiousness variables to model 2 explained an additional $3 \%$ of the variance in deconversion $[F(4,210)=3.76, p<0.006)]$. In model 2, mother's care was also the only significant negative predictor of deconversion. Adding social support variables to model 3 explained an additional $3 \%$ of the variance in deconversion $[F(6,210)=3.81, p=0.001]$. In model 3 , mother's care and friends' support significantly and negatively predicted deconversion. Significant others' support was the third factor, which almost reached the required level of statistical significance in predicting deconversion in adolescents; however, support from significant others was positively related to deconversion. These four factors accounted for $21 \%$ of the variance in deconversion. A summary of the regression analysis for variables predicting deconversion is reported in Table 4. 
Table 4. Summary of Hierarchical Regression Analysis for Variables Predicting Deconversion.

\begin{tabular}{cccccc}
\hline \multicolumn{2}{c}{ Model/Variables } & $\boldsymbol{B}$ & Beta & $\boldsymbol{t}$ & $\boldsymbol{p}$ \\
\hline Model 1 & Constant & 0.98 & & 19.19 & 0.001 \\
& Care M & -0.15 & -0.19 & -2.47 & 0.014 \\
& Care F & 0.02 & 0.03 & 0.32 & 0.750 \\
\hline Model 2 & Constant & 0.99 & & 19.58 & 0.001 \\
& Care M & -0.17 & -0.22 & -2.79 & 0.006 \\
& Care F & 0.06 & 0.09 & 1.04 & 0.297 \\
& Religiousness M & -0.05 & -0.07 & -0.82 & 0.415 \\
& Religiousness F & -0.11 & -0.14 & -1.62 & 0.107 \\
\hline \multirow{2}{*}{ Model 3 } & Constant & 0.99 & & 19.71 & 0.001 \\
& Care M & -0.17 & -0.23 & -2.58 & 0.011 \\
& Care F & 0.09 & 0.12 & 1.45 & 0.150 \\
& Religiosity M & -0.06 & -0.07 & -0.86 & 0.392 \\
& Religiosity F & -0.12 & -0.15 & -1.71 & 0.090 \\
& Friends' Support & -0.20 & -0.27 & -2.66 & 0.008 \\
& Family's Support & 0.03 & 0.03 & 0.32 & 0.752 \\
& Others' Support & 0.12 & 0.17 & 1.71 & 0.088 \\
\hline
\end{tabular}

\section{Discussion}

The present study was focused on predictors of deconversion in adolescence. Parental factors-parental care and religiousness—and social support—from friends, family, and significant others-were tested as variables potentially related to deconversion in adolescents. The results showed that caring and religious parents are factors that protect adolescents from deconversion, particularly from faith abandonment and moral criticism. The least inclined to abandon faith and to criticize moral rules derived from religion are those adolescents whose parents are both caring and religious. Perceived social support also differentiated respondents in their inclination to deconversion. Adolescents who receive low social support have a higher tendency to abandon faith and to criticize moral religious teaching than those adolescents who receive at least moderate support. Experiencing transcendental emptiness was also significantly higher in the group with low social support than in the group with high social support. Regression analyses revealed that the mother's care as well as friends' support are negative predictors of deconversion among adolescents.

The results obtained in this study showed that caring and religious parents are very important factors protecting adolescents from deconversion. This is in line with previous studies concerning parental predictors of religiousness (Buchbinder et al. 1997; Flor and Knapp 2001; Goodman and Dyer 2020; Smith and Denton 2005; Spilman et al. 2013; Ullman 1989). Research suggests that while parental religiousness is the best single predictor of their offspring's religiousness, parental insensitivity is a significant limiting factor, particularly insufficient mother's care. When parents embrace a supportive, communicative, and nurturing nature, the likelihood of faith transmission to their adolescents increases (Hardy et al. 2011; Hoge et al. 1982; Myers 1996; Okagaki and Bevis 1999) and the likelihood of the adolescents moving away from their parents' religion decreases (Longo and Kim-Spoon 2014). This finding is consistent with theories where parental religious beliefs are more likely to be transmitted when parents maintain a close, intimate bond with their adolescents (Bronfenbrenner 2000; Goodman and Dyer 2020). The practical application of these results is that if religious parents would like to protect their children from abandoning the religious belief system, they should combine religious messages with caring attitudes that meet the needs of protection and safety (Granqvist and Kirkpatrick 2013). These findings support our Hypothesis 1, which claimed that high religiosity of parents and high parental care are negatively associated with deconversion in adolescents. Faith abandonment and moral criticism are two deconversion processes significantly weakened by parents' religiosity and caring attitude. 
According to our Hypothesis 2, social support was also confirmed as a protective factor against deconversion processes. Teenagers had a significantly higher tendency to abandon faith and to criticize moral religious teaching when their social support was low. Additionally, experiencing transcendental emptiness was higher in the low social support group than in the high social support one. This result is consistent with some previous studies which showed positive relationships between social support and religious involvement (Erickson 1992; Pearce et al. 2019). It was also found that social factors such as the relationship quality, community connection, and spiritual support predicted religious identity and motivation (Donaldson et al. 2019).

In Poland, the Roman Catholic religion creates a sociocultural context, and in most cases, a religious person entails social approval (Mandes and Rogaczewska 2013; Mariański 2011; Vrublevskaya et al. 2019). The social network, which is built on shared values and philosophy of life, is conducive to discussing questions about moral rules in everyday life, and as a result it can deepen adolescents' faith and support religiosity. This outcome seems to be reflected in our sample. Most of our respondents had been brought up in religious families, and almost the same percentage of participants had a positive attitude to religion. Among our participants, 55.2\% $(n=128)$ declared that they were religious or very religious. Among the respondents' parents there were $171(73.7 \%)$ religious or very religious mothers and $131(56.5 \%)$ religious or very religious fathers, as attested by the participants. On the other hand, almost $45 \%$ of our sample declared rather weak or no religiosity. This may be related to weaker religiosity of their parents, and-according to Hypothesis 1-to a low quality of the relationship between parents and children. However, social support cannot be understood only as family support. In the adolescent period, support from peers is even more important (which is in line with our Hypothesis 3). At the same time, in modern society today, young Polish people have a frequent and strong experience of dissatisfaction with their social relationships and loneliness (Sroczyńska 2020). Loneliness and consequently lack of social support can manifest themselves first in experiencing transcendental emptiness, then in moral criticism, and finally in abandoning faith, which can be observed in the results of our study.

As we expected according to Hypothesis 3 , the regression analysis showed that support from friends (apart from the mother's caring attitude) is a significant factor negatively predicting deconversion processes. This result means that the availability of support from friends protects against deconversion. This finding is consistent with the literature that emphasizes the important role of peers in adolescence (Brown 1990; Steinberg and Morris 2001). According to Fowler (1981), the period of adolescence corresponds to the third stage in the development of faith, where a new look at the relationship to God is made, accompanied by a kind of conformism, consisting in the need to rely on the authority and support of others. Who are the others? As mentioned earlier, parents' influence on teenagers' behaviour and development weakens (Harris 1995; Larson and Richards 1991; Steinberg and Morris 2001). Instead of this parental influence, close friends and peers become the primary source of social and emotional support for youth (Wilkinson 2004). As peers and friends represent the main agents in the development of social connectedness and interpersonal relationships in adolescence (Armsden and Greenberg 1987; Gorrese and Ruggieri 2012), support from these individuals seems to be crucial in the third stage of faith development (Fowler 1981). The other option is support from significant others. In our study, we found a positive (marginally insignificant) relationship between significant others' support and deconversion processes. It is conceivable that significant others may strengthen deconversion processes, especially when the mother's care and friends' support is low and youth feel rejected. When looking for acceptance, support, and authority, young people can find these characteristics in any person, who thus becomes a significant other. This person may come from an adolescent's immediate environment but also from the media or pop culture. According to social learning theory (Bandura 1979), such a person may serve as a model figure, whose religious attitude may direct adolescents towards or away from religion. Social and cultural changes show that a lot of young people in Poland are trying to figure out their own ways of balancing faith with the conditions 
of modern life and culture (Mandes and Rogaczewska 2013). This means that teenagers can look for religion in love, music, or heathy slow life, if a significant other proposes such a view of the world.

Our research has some limitations. First, predictors of deconversion were examined in a culture highly homogeneous in terms of religion, almost exclusively Catholic. Given this, deconversion is essentially leaving religion as there are few additional choices. This fact makes this study heavily culturally linked and difficult to generalize results to other populations. But, as Streib (2020) noted, "cultural differences, or more specifically: differences between the various religious actors within and across these religious fields, may generate a variety of different versions of deconversion (p. 7). Second, the measures used in the present study were based on self-reports, and it would be beneficial in future studies to go beyond self-report and include qualitative data, for example. Third, the weakness of this study is using cross sectional data to suggest a causal pattern that can only be established with longitudinal data. Future research should employ a longitudinal design also with the stages of adolescence to examine how deconversion processes change over time.

\section{Conclusions}

To conclude, the main aim of this study was to analyse the relationships among parental factors and social support with deconversion processes in adolescents. The results highlighted the significant role of parental care and social support in predicting deconversion, particularly in faith abandoning and moral criticism. It is worth emphasizing that parents, who care about the quality of their relationships with their children, protect them from abandoning religious beliefs.

Author Contributions: Conceptualisation, M.Ł., B.Z., and M.P.-W.; methodology, M.Ł., B.Z., and M.P.-W.; formal analysis, B.Z.; investigation, M.Ł.; data curation, M.Ł.; funding acquisition, M.Ł., B.Z., and M.P.-W.; writing (original draft preparation), M.Ł., B.Z., and M.P.-W; writing (review and editing), M.Ł., B.Z., and M.P.-W. All authors have read and agreed to the published version of the manuscript.

Funding: The Article Processing Charge was funded by the authors' university.

Conflicts of Interest: The authors declare no conflict of interest.

\section{References}

Ainsworth, Mary D. Salter, Mary C. Blehar, Everett Waters, and Sally N. Wall. 1978. Patterns of Attachment: A Psychological Study of the Strange Situation. Hillsdale: Erlbaum.

Armsden, Gay C., and Mark T. Greenberg. 1987. The Inventory of Parent and Peer Attachment: Individual differences and their relationship to psychological well-being in adolescence. Journal of Youth and Adolescence 16: 427-54. [CrossRef] [PubMed]

Arnett, Jeffrey J. 2000. Emerging adulthood: A theory of development from the late teens through the twenties. American Psychologist 55: 469-80. [CrossRef]

Bandura, Albert. 1979. Self-referent mechanisms in social learning theory. American Psychologist 34: 439-41. [CrossRef]

Barbour, John D. 1994. Versions of Deconversion: Autobiography and the Loss of Faith. Charlottesville: University Press of Virginia.

Bowlby, John. 1991. Attachment and Loss. Harmondsworth: Penguin Books, New York: Viking Penguin.

Boyatzis, Chris J., David C. Dollahite, and Loren D. Marks. 2006. The Family as a Context for Religious and Spiritual Development in Children and Youth. The Handbook of Spiritual Development in Childhood and Adolescence. Thousand Oaks: Sage, pp. 297-309.

Brambilla, Maria, Avi Assor, Claudia Manzi, and Camillo Regalia. 2015. Autonomous versus controlled religiosity: Family and group antecedents. International Journal for the Psychology of Religion 25: 193-210. [CrossRef]

Bronfenbrenner, Urie. 2000. Ecological systems theory. In Encyclopedia of Psychology. Edited by Alan E. Kazdin. Washington, DC and New York: American Psychological Association Oxford University Press, vol. 3, pp. 129-33.

Brown, B. Bradford. 1990. Peer groups and peer cultures. In At the Threshold: The Developing Adolescent. Edited by S. S. Feldman and G. R. Elliott. Cambridge: Harvard University Press, pp. 171-96. 
Buchbinder, Jacob. T., Yoram Bilu, and Ely Witztum. 1997. Ethnic background and antecedent of religious conversion among Israeli Jewish outpatients. Psychological Reports 81: 1187-202. [CrossRef]

Camara, Maria, Gonzalo Bacigalupe, and Patricia Padilla. 2017. The role of social support in adolescents: Are you helping me or stressing me out? International Journal of Adolescence and Youth 22: 123-36. [CrossRef]

Desmond, Scott A., Kristopher H. Morgan, and George Kikuchi. 2010. How (and why) does religiosity change from adolescence to young adulthood? Sociological Perspectives 53: 247-70. [CrossRef]

Desrosiers, Alethea, Brien S. Kelley, and Lisa Miller. 2011. Parent and peer relationships and relational spirituality in adolescents and young adults. Psychology of Religion and Spirituality 3: 39-54. [CrossRef]

Donaldson, Keren, Myron D. Friesen, and Jeffrey D. Gage. 2019. The psychological salience of religiosity and spirituality among Christian young people in New Zealand: A mixed-methods study. Psychology of Religion and Spirituality 11: 42-54. [CrossRef]

Dubow, Erik F., Kenneth R. Lovko Jr., and Donald F. Kausch. 1990. Demographic differences in adolescents' health concerns and perceptions of helping agents. Journal of Clinical Child Psychology 19: 44-54. [CrossRef]

Ecklund, Elaine H., and Jerry Z. Park. 2007. Religious Diversity and Community Volunteerism Among Asian Americans. Journal for the Scientific Study of Religion 46: 233-44. [CrossRef]

Erickson, Joseph A. 1992. Adolescent religious development and commitment: A structural equation model of the role of family, peer group, and educational influences. Journal for the Scientific Study of Religion 31: 131-52. [CrossRef]

Erikson, Erik H. 1963. Childhood and Society, 2nd ed. New York: Norton.

Exline, Julie J., Steffany J. Homolka, and Joshua B. Grubbs. 2013. Negative Views of Parents and Struggles with God: An Exploration of Two Mediators. Journal of Psychology \& Theology 41: 200-12.

Flor, Douglas L., and Nancy F. Knapp. 2001. Transmission and transaction: Predicting adolescents' internalization of parental religious values. Journal of Family Psychology 15: 627-45. [CrossRef] [PubMed]

Fowler, James W. 1981. Stages of Faith: The Psychology of Human Developement and the Quest for Meaning. San Francisco: Harper \& Row Publishers.

George, Darren, and Paul Mallery. 2010. SPSS for Windows Step by Step: A Simple Guide and Reference, 17.0 Update, 10a ed. Boston: Pearson.

Goodman, Michael A., and Justin W. Dyer. 2020. From parent to child: Family factors that influence faith transmission. Psychology of Religion and Spirituality 12: 178-90. [CrossRef]

Gorrese, Anna, and Ruggero Ruggieri. 2012. Peer attachment: A meta-analytic review of gender and age differences and associations with parent attachment. Journal of Youth and Adolescence 41: 650-72. [CrossRef]

Granqvist, Pehr, and Berit Hagekull. 2003. Longitudinal Predictions of Religious Change in Adolescence: Contributions from the Interaction of Attachment and Relationship Status. Journal of Social and Personal Relationships 20: 793-817. [CrossRef]

Granqvist, Pehr, and Lee A. Kirkpatrick. 2013. Religion, Spirituality, and Attachment. In APA Handbook of Psychology, Religion, and Spirituality (Vol 1): Context, Theory, and Research. Edited by Kenneth I. Pargament, Julie J. Exline and J. W. Jones. APA Handbooks in Psychology. Washington, DC: American Psychological Association, pp. 139-55.

Granqvist, Pehr, Tord Ivarsson, Anders G. Broberg, and Berit Hagekull. 2007. Examining Relations among Attachment, Religiosity, and New Age Spirituality Using the Adult Attachment Interview. Developmental Psychology 43: 590-601. [CrossRef]

Greenwald, Yaakov, Mario Mikulincer, Pehr Granqvist, and Phillip R. Shaver. 2018. Apostasy and conversion: Attachment orientations and individual differences in the process of religious change. Psychology of Religion and Spirituality 28: 260-70. [CrossRef]

Griffiths, Kathleen M., Dimity A. Crisp, Lisa Barney, and Russell Reid. 2011. Seeking help for depression from family and friends: A qualitative analysis of perceived advantages and disadvantages. BMC Psychiatry 11: 196. [CrossRef]

Guzik, Aldona, Radosław Marzęcki, and Łukasz Stach. 2015. Pokolenie'89. Aksjologia i aktywność młodych Polaków. Kraków: Wydawnictwo Naukowe Uniwersytetu Pedagogicznego.

Hair, Joseph F., William Black, Barry J. Babin, and Rolph E. Anderson. 2010. Multivariate Data Analysis, 7th ed. Upper Saddle River: Pearson Education International.

Halama, Peter, Marta Gašparíková, and Matej Sabo. 2013. Relationship between attachment styles and dimensions of the religious conversion process. Studia Psychologica 55: 195-207. [CrossRef] 
Hardy, Sam A., Jennifer A. White, Zhiyong Zhang, and Joshua Ruchty. 2011. Parenting and the socialization of religiousness and spirituality. Psychology of Religion and Spirituality 3: 217-30. [CrossRef]

Harris, Judith. 1995. Where is the child's environment? A group socialization theory of development. Psychological Review 102: 458-89. [CrossRef]

Heinrich, Lisl M., and Eleonora Gullone. 2006. The clinical significance of loneliness: A literature review. Clinical Psychology Review 26: 695-718. [CrossRef] [PubMed]

Hoge, Dean R., Gregory H. Petrillo, and Ella I. Smith. 1982. Transmission of religious and social values from parents to teenage children. Journal of Marriage and the Family 44: 569-79. [CrossRef]

Khasmohammadi, Mahdi, Sara Ghazizadeh Ehsaei, Wouter Vanderplasschen, Fariborz Dortaj, Kioumars Farahbakhsh, Hossein Keshavarz Afshar, Zahra Jahanbakhshi, Farshad Mohsenzadeh, Sidek Mohd Noah, Tajularipin Sulaiman, and et al. 2020. The Impact of Addictive Behaviors on Adolescents Psychological Well-Being: The Mediating Effect of Perceived Peer Support. Journal of Genetic Psychology 181: 39-53. [CrossRef]

Kim, Sangwon, and Gissele B. Esquivel. 2011. Adolescent spirituality and resilience: Theory, research, and educational practices. Psychology in the Schools 48: 755-65. [CrossRef]

Kirkpatrick, Lee A., and Philip R. Shaver. 1990. Attachment theory and religion: Childhood attachments, religious beliefs and conversion. Journal for the Scientific Study of Religion 29: 315-34. [CrossRef]

Larson, Reed, and Maryse H. Richards. 1991. Daily companionship in late childhood and early adolescence: changing developmental contexts. Child Development 62: 284-300. [CrossRef]

Leonard, Kathleen C., Kaye Cook, Chris Boyatzis, Cynthia N. Kimball, and Kelly S. Flanagan. 2013. Parent-child dynamics and emerging adult religiosity: Attachment, parental beliefs, and faith support. Psychology of Religion and Spirituality 5: 5-14. [CrossRef]

Longo, Gregory S., and Jungmeen Kim-Spoon. 2014. What drives apostates and converters? The social and familial antecedents of religious change among adolescents. Psychology of Religion and Spirituality 6: 284-91. [CrossRef] [PubMed]

Łysiak, Małgorzata, and Piotr Oleś. 2017. Temporal dialogical activity and identity formation during adolescence. International Journal for Dialogical Science 1: 1-18.

Mandes, Sławomir, and Maria Rogaczewska. 2013. “I don't reject the Catholic Church—the Catholic Church rejects me": How Twenty- and Thirty-somethings in Poland Re-evaluate their Religion. Journal of Contemporary Religion 28: 259-76. [CrossRef]

Mariański, Janusz. 2011. Tendencje rozwojowe w polskim katolicyzmie-Diagnoza i prognoza. Teologia Praktyczna 12: 7-24. [CrossRef]

McDonald, Angie, Richard Beck, Steve Allison, and Larry Norswortby. 2005. Attachment to God and Parents: Testing the Correspondence vs. Compensation Hypotheses. Journal of Psychology \& Christianity 24: 21-28.

Myers, Scott M. 1996. An Interactive Model of Religiosity Inheritance: The Importance of Family Context. American Sociological Review 61: 858-66. [CrossRef]

Nica, Andreea. 2019. Exiters of religious fundamentalism: Reconstruction of social support and relationships related to well-being. Mental Health, Religion \& Culture 22: 543-56. [CrossRef]

Nowosielski, Mirosław, and Rafał P. Bartczuk. 2017. Analiza Strukturalna Procesów Dekonwersji w Okresie Dojrzewania-Konstrukcja Skali Dekonwersji Adolescentów. Roczniki Psychologiczne/Annals of Psychology 20: 143-65. [CrossRef]

Offer, Daniel, Kenneth I. Howard, Kimberly A. Schonert, and Erik J.D. Ostrov. 1991. To Whom Do Adolescents Turn for Help? Differences between Disturbed and Nondisturbed Adolescents. Journal of the American Academy of Child and Adolescent Psychiatry 30: 623-30. [CrossRef]

Okagaki, Lynn, and Claudia Bevis. 1999. Transmission of religious values: Relations between parents' and daughters' beliefs. The Journal of Genetic Psychology 160: 303-18. [CrossRef]

Paloutzian, Raymond F., Sebastian Murken, Heinz Streib, and Sussan Rößler-Namini. 2013. Conversion, Deconversion, and Transformation: A Multilevel Interdisciplinary View. In Handbook of the Psychology of Religion and Spirituality, 2nd ed. New York: Guilford Press, pp. 399-421.

Park, Crystal L., and Jeanne M. Slattery. 2013. Religion, Spirituality, and Mental Health. In Handbook of the Psychology of Religion and Spirituality. Edited by Raymond F. Paloutzian and Crystal L. Park. New York: The Guilford Press, pp. 540-59. 
Parker, Gordon, Hilary Tupling, and L.B. Brown. 1979. A Parental Bonding Instrument. British Journal of Medical Psychology 52: 1-10. [CrossRef]

Pearce, Lisa D., Jeremy E. Uecker, and Melinda Lundquist Denton. 2019. Religion and Adolescent Outcomes: How and under What Conditions Religion Matters. Annual Review of Sociology 45: 201-22. [CrossRef]

Petts, Richard J. 2009. Trajectories of religious participation from adolescence to young adulthood. Journal for the Scientific Study of Religion 48: 552-71. [CrossRef]

Smith, Christian, and Melina Lundquist Denton. 2005. Soul Searching: The Religious and Spiritual Lives of American Teenagers. New York: Oxford University Press. [CrossRef]

Spilman, Sarah K., Tricia K. Neppl, Brent M. Donnellan, Thomas J. Schofield, and Rand D. Conger. 2013. Incorporating religiosity into a developmental model of positive family functioning across generations. Developmental Psychology 49: 762-74. [CrossRef]

Sroczyńska, Maria. 2020. Młodzież w poszukiwaniu sacrum. Rozważania socjologiczne. Przeglad Religioznawczy 2: 113-28. [CrossRef]

Steinberg, Laurence, and Amanda S. Morris. 2001. Adolescent development. Annual Review of Psychology 52: 83-110. [CrossRef]

Streib, Heinz. 2020. Leaving Religion: Deconversion. Current Opinion in Psychology 40: 139-44. [CrossRef]

Streib, Heinz, and Barbara Keller. 2004. The Variety of Deconversion Experiences: Contours of a Concept in Respect to Empirical Research. Archive for the Psychology of Religion 26: 181-200. [CrossRef]

Ullman, Chana. 1989. The Transformed Self. The Psychology of Religious Conversion. New York: Plenum Press.

Vrublevskaya, Polina, Marcus Moberg, and Sławomir Sztajer. 2019. The role of grandmothers in the religious socialization of young adults in post-socialist Russia and Poland. Religion 49: 201-20. [CrossRef]

Wilkinson, Ross B. 2004. The role of parental and peer attachment in the psychological health and self-esteem of adolescents. Journal of Youth and Adolescence 33: 479-93. [CrossRef]

Zarzycka, Beata. 2009. Tradition or Charisma. Religiosity in Poland. In What the World Believes: Analysis and Commentary on the Religion Monitor 2008. Edited by Bertelsmann Stiftung. Gütersloh: Verlag Bertelsmann Stiftung, pp. 201-22.

Zarzycka, Beata. 2018. Parental Attachment Styles and Religious and Spiritual Struggle: A Mediating Effect of God Image. Journal of Family Issues, 1-19. [CrossRef]

Zarzycka, Beata, and Elżbieta Rydz. 2014. Explaining the Relationship between Post-Critical Beliefs and Sense of Coherence in Polish Young, Middle, and Late Adults. Journal of Religion and Health 53: 834-48. [CrossRef] [PubMed]

Zimet, Gregory D., Nancy W. Dahlem, Sara G. Zimet, and Gordon K. Farley. 1988. The Multidimensional Scale of Perceived Social Support. Journal of Personality Assessment 52: 30-41. [CrossRef]

Publisher's Note: MDPI stays neutral with regard to jurisdictional claims in published maps and institutional affiliations.

(C) 2020 by the authors. Licensee MDPI, Basel, Switzerland. This article is an open access article distributed under the terms and conditions of the Creative Commons Attribution (CC BY) license (http://creativecommons.org/licenses/by/4.0/). 